\title{
PENGOLAHAN LIMBAH CAIR RUMAH SAKIT DENGAN METODE KOAGULASI, FENTON DAN ADSORPSI
}

\author{
Dian Kurnia Sari ${ }^{1)}$, Nopitasari ${ }^{2)}$ \\ ${ }^{1,2)}$ Program studi Teknik Analisis Laboratorium Migas Politeknik Akamigas Palembang, 30257, Indonesia
}

\begin{abstract}
Abstrak: Limbah rumah sakit mengandung mikroorganisme patogen, bahan kimia beracun yang menimbulkan penyakit infeksi, bahan yang susah diurai, radioaktif yang dapat menyebabkan polusi dan masalah kesehatan. Keberadaan rumah sakit yang dekat dengan lingkungan masyarakat dapat menimbulkan masalah lingkungan akibat limbah dibuang ke lingkungan. Tujuan dari penelitian ini adalah mempelajari variabel-variabel yanng berpengaruh terhadap penurunan pencemar seperti BOD, COD dan TSS pada limbah cair rumah sakit sehingga sesuai baku mutu lingkungan. Penelitian ini dilakukan dengan tiga metode :1) metode koagulasi dengan koagulan tawas (1.000, 1.250, 1.500, 1.750 dan $2.000 \mathrm{ppm}$ ). 2) penambahan reagen fenton. 3) adsorbsi menggunakan karbon aktif dengan laju alir 80, 110 dan $140 \mathrm{~mL} /$ menit dan tinggi unggun 30,40 dan $50 \mathrm{~cm}$. Hasil penelitian ini menunjukkan konsentrasi tawas yang optimum adalah $1750 \mathrm{ppm}$ dengan efisiensi penurunan BOD 58,9 \%, COD 55,3 \% dan TSS 69,2 \%, dengan penambahan fenton efisiensi penurunan BOD $75 \%$, COD $51 \%$ dan TSS $46 \%$ dan pada karbon aktif kondisi paling optimum dengan variasi laju alir $80 \mathrm{~mL} /$ menit dan tinggi karbon $50 \mathrm{~cm}$, efisiensi penurunan BOD 75,11\%, COD 72,69 dan TSS 80,65\%.
\end{abstract}

Kata kunci : alumunium sulfat, fenton, adsorpsi, karbon aktif

\section{PENDAHULUAN}

\section{Latar Belakang}

Dengan mengacu pada PP
No.1204/MENKES/X/2004
persyaratan kesehatan lingkungan rumah sakit, bahwa rumah sakit sebagai sarana pelayanan kesehatan, tempat berkumpulnya orang sakit maupun orang sehat dapat menjadi tempat penularan penyakit serta memungkinkan terjadinya pencemaran lingkungan dan gangguan rumah sakit.

Rumah sakit sebagai unit terbesar dan terkompleks dalam fungsi pelayanan kesehatan tidak hanya memegang peranan penting dalam upaya penyehatan masyarakat tetapi juga memiliki tanggungjawab pada upaya penyehatan masyarakat yang tidak hanya sebatas pada upaya penyembuhan dari pasiennya sesuai paradigma lama yang berlaku selama ini, akan tetapi juga bertanggung jawab pada keseimbangan kehidupan sebelum penyakit menyerang pasiennya, hal ini berkaitan dengan kemampuannya dalam menerapkan manajemen lingkungan baik yang berlaku dan berdampak langsung pada internal rumah sakit tersebut beserta isinya maupun yang berlaku external pada lingkungan diluar rumah sakit beserta masyarakat yang hidup dan tinggal disekitarnya.

Alternatif pengolahan air bersih dan limbah dewasa ini, cenderung mengarah ke pengolahan dengan membran dan juga pengolahan secara kimia dikarenakan komposisi kontaminan semakin kompleks dan semakin sulit diurai oleh mikroba. Salah satu teknologi pengolahan secara kimiawi tersebut adalah Advanced Oxidation Processes (AOPs) atau proses-proses oksidasi tingkat lanjut yang merupakan teknologi pengolahan air bersih dan air limbah dengan prinsip oksidasi lanjut menggunakan oksidator kuat dan dapat dikombinasikan dengan proses sedimentasi (koagulasi-flokulasi). Prinsip oksidasi ini terkait dengan proses kimia terhadap senyawa organik, sedangkan bila terkait dengan logam berat maka yang terjadi adalah proses destruksi ikatan kimia dari logam tersebut, yang kemudian diendapkan dengan koagulan. Proses oksidasi tingkat lanjut merupakan alternatif metode pengolahan air limbah post treatment rumah sakit yang cukup ekonomis karena mampu menghemat tempat, hemat energi, biaya investasi murah, amansederhana, proses pengolahannya cepat, cukup efektif dan air hasil olahan dapat dimanfaatkan kembali (Scrudato and Chiarenzelli, 2000) 
Reagen fenton adalah senyawa peroksida yang direaksikan dengan katalis $\mathrm{Fe}^{2+}\left(\mathrm{FeSO}_{4}\right)$ kemudian akan menghasilkan hidroksil radikal $\left({ }^{*} \mathrm{OH}\right)$ yang efektif mengoksidasi senyawa-senyawa lain. Fenton telah dikembangkan di banyak tempat untuk mengolah bahan organik Biological Oxygen Demand/Chemical Oxygen Demand (BOD/COD), Total Suspended Solid (TSS), warna, nitrogen, fosfor dan sebagian logam yang terkandung dalam air limbah domestik industri maupun air baku air minum. Koagulan alum $\left(\mathrm{Al}_{2}\left(\mathrm{SO}_{4}\right)_{3}\right)$ telah banyak dikenal dan dimanfaatkan secara luas oleh masyarakatindustri terkait dengan pengurangan partikel koloid dalam air yang cukup murah dan efektif. Koagulan feri sulfat $\left(\mathrm{Fe}_{2}\left(\mathrm{SO}_{4}\right)_{3}\right)$ mempunyai kemampuan mengurangi kekeruhan-warna cukup besar. PAC /Polyaluminium Chloride $\left(\mathrm{Al}_{10}(\mathrm{OH}) 15 \mathrm{Cl}_{15}\right)$ umum dipakai dibanyak industri terkait dengan efisiensi jumlah koagulan yang dipakai. Potasium ferat VI $\left(\mathrm{K}_{2} \mathrm{FeO}_{4}\right)$ memiliki tingkat keefisienan yang cukup tinggi terutama dalam pengurangan kekeruhan dan kandungan bahan organik sebagai COD

\section{TEORI DASAR}

\section{1 . Limbah Rumah Sakit}

Limbah rumah sakit adalah semua limbah yang dihasilkan oleh kegiatan rumah sakit dan kegiatan penunjang lainnya. Mengingat dampak yang mungkin timbul, maka diperlukan upaya pengelolaan yang baik meliputi alat dan sarana, keuangan dan tatalaksana pengorganisasian yang ditetapkan dengan tujuan memperoleh kondisi rumah sakit yang memenuhi persyaratan kesehatan lingkungan. Limbah rumah sakit bisa mengandung bermacam - macam mikroorganisme bergantung pada jenis rumah sakit. Limbah cair rumah sakit dapat mengandung bahan organik dan anorganik yang umumnya diukur dengan parameter BOD, COD, TSS, dan lain-lain. Sedangkan limbah padat rumah sakit terdiri atas sampah mudah membusuk, sampah mudah terbakar, dll. Limbah-limbah tersebut kemungkinan besar mengandung mikroorganisme patogen atau bahan kimia beracun berbahaya yang menyebabkan penyakit infeksi dan dapat tersebar ke lingkungan rumah sakit yang disebabkan oleh teknik pelayanan kesehatan yang kurang memadai, kesalahan penanganan bahan-bahan terkontaminasi dan peralatan, serta penyediaan dan pemeliharaan sarana sanitasi yang nasib buruk. Pembuangan limbah yang berjumlah cukup besar ini paling baik jika dilakukan dengan memilah-milah limbah ke dalam berbagai kategori. Untuk masingmasing jenis kategori diterapkan cara pembuangan limbah yang berbeda. Prinsip umum pembuangan limbah rumah sakit adalah sejauh mungkin menghindari risiko kontaminasi dan trauma (injury).

Definisi limbah cair rumah sakit menurut Keputusan Menteri Kesehatan No. 1204 tahun 2004 adalah semua air buangan termasuk tinja yang berasal dari kegiatan rumah sakit yang memungkinkan mengandung mikroorganisme, bahan kimia beracun dan radioaktif yang berbahaya bagi kesehatan. Sumber limbah cair berasal dari bangunan unit rawat inap, unit rawat jalan penunjang medis dan non medis, bangunan umum dan ruang terbuka. Bahwa kegiatan rumah sakit mempunyai potensi menghasilkan limbah yang dapat menimbulkan pencemaran lingkungan hidup. Oleh karena itu, perlu dilakukan pengendalian terhadap pembuangan limbah cair yang dibuang ke lingkungan. Sehingga sangat perlu mengurangi pencemaran tersebut dengan pengelolaan limbah yang baik dan sesuai peraturan perundang-undangan. Penelitian ini mendasarkan pada peraturan perundangundangan yaitu Peraturan Gubernur Nomor 8 tahun 2012 tentang Baku Mutu Limbah Cair Bagi Kegiatan Rumah Sakit dan Peraturan Gubernur Nomor 16 Tahun 2005 tentang Peruntukan air dan baku mutu air sungai.

\subsection{Koagulasi}

Koagulasi adalah dicampurkannya koagulan dengan pengadukan secara cepat koloid dan solid tersuspensi yang halus, dan masa inti partikel, kemudian membentuk jonjot mikro (mikro flok). Koagulasi didefinisikan sebagai proses destabilisasi 
muatan koloid padatan tersuspensi termasuk bakteri dan virus, dengan suatu koagulan. sehingga akan terbentuk flok-flok halus yang dapat diendapkan, proses pengikatan partikel koloid dapat dilihat pada gambar. Pengadukan cepat (flash mixing) merupakan bagian integral dari proses koagulasi. Tujuan pengadukan cepat adalah untuk mempercepat dan menyeragamkan penyebaran zat kimia melalui air yang diolah , jenis partikel koloid merupakan penyebab kekeruhan dalam air (efek Tyndall) yang disebabkan oleh penyimpangan sinar nyata yang menembus suspensi tersebut. Partikel-partikel koloid tidak terlihat secara visual sedangkan larutannnya (tanpa partikel koloid) yang terdiri dari ion-ion dan molekul-molekul tidak pernah keruh.

Larutan tidak keruh jika terjadi pengendapan (presipitasi) yang merupakan keadaan kejenuhan dari suatu senyawa kimia. Metcalf dan Eddy (1991), menyatakan bahwa untuk mendorong pembentukan agregat pertikel, harus diambil langkah-langkah tertentu guna mengurangi muatan atau mengatasi pengaruh muatan partikel. Pengaruh muatan dapat diatasi dengan : (1) penambahan ion berpotensi menentukan muatan sehingga terserap atau bereaksi dengan permukaan koloid untuk mengurangi muatan permukaan, atau penambahan elektrolit yang akan memberikan pengaruh mengurangi ketebalan lapisan difusi listrik sehingga mengurangi zeta potensial, (2) penambahan molekul organik berantai panjang (polimer) yang subbagiannya dapat diberi muatan sehingga disebut polielektrolit, hal ini menyebabkan penghilangan partikel melalui adsorbsi dan pembuatan penghubung (bridging), dan (3) penambahan bahan kimia yang membentuk ion-ion yang terhidrolisis oleh logam. Koagulan yang umum dipakai adalah alumunium sulfat, feri sulfat, fero sulfat dan PAC.

Mekanisme pengendapan dengan koagulan pada partikel koloid, berkaitan dengan muatan listrik pada partikel koloid tersebut. Umumnya partikel koloid alam bermuatan negatif. Partikel koloid memiliki muatan yang sama satu sama lain. Akibatnya, partikel koloid tolak - menolak satu sama lain sehingga pembentukan partikel yang lebih besar menjadi terhalang. Koagulan yang mengandung muatan yang berlawanan dengan muatan partikel koloid akan menyerap koloid tersebut pada permukaannya dan menurunkan gaya tolak - menolak antar partikel koloid sehingga partikel tidak terhalang lagi untuk membentuk partikel yang lebih besar dan dapat mengendap (Aminzadeh et al. 2007).

Pengadukan cepat yang efektif sangat penting ketika menggunakan koagulan logam seperti alum dan ferric chloride, karena proses hidrolisnya terjadi dalam hitungan detik dan selanjutnya terjadi adsorpsi partikel koloid. Waktu yang dibutuhkan untuk zat kimia lain seperti polimer (polyelectrolites), chlorine, zat kimia alkali, ozone, dan potassium permanganat, tidak optimal karena tidak mengalami reaksi hidrolisis.

\subsection{Proses Oksidasi Lanjutan (Fenton Process)}

Reagen antara hidrogen peroksida $\left(\mathrm{H}_{2} \mathrm{O}_{2}\right)$ dengan katalis besi disebut juga reagen Fenton. Hidrogen peroksida merupakan salah satu oksidator yang lazim digunakan. Oksidator ini memiliki kandungan oksigen aktif yang tinggi. Kandungan oksigen aktif ini berpengaruh pada penekanan biaya proses (Strukul 1992). Hidrogen peroksida mudah sekali terdekomposisi menjadi oksigen dan air. Faktor-faktor yang dapat memengaruhi dekomposisi hidrogen peroksida ialah suhu dan pH (Strukul 1992). Reaksi hidrogen peroksida sangat lambat sehingga membutuhkan katalis. Katalis yang umum digunakan adalah besi sulfat $\left(\mathrm{FeSO}_{4}\right)$ (Eckenfelder 2000).

Reagen Fenton menggunakan radikal hidroksil sebagai gugus reaktif dan besi sebagai katalis pembentukan radikal hidroksil tersebut (Eckenfelder 2000).

Reaksi pembentukan radikal hidroksil sebagai berikut :

$$
\begin{aligned}
& \mathrm{Fe}^{2+}+\mathrm{H}_{2} \mathrm{O}_{2} \rightarrow \mathrm{Fe}^{3+}+\mathrm{OH}^{-}+. \mathrm{OH} \\
& \mathrm{Fe}^{3+}+\mathrm{H}_{2} \mathrm{O}_{2} \rightarrow \mathrm{Fe}^{2+}+. \mathrm{OOH}+\mathrm{H}^{+}
\end{aligned}
$$

Reaksi tersebut menghasilkan radikal bebas $\cdot \mathrm{OH}$, serta pembentukan kembali 
$\mathrm{Fe}^{2+}$ (Eckenfelder 2000). Besi feri dapat berubah kembali menjadi besi fero pada reaksi selanjutnya dengan kelebihan molekul $\mathrm{H}_{2} \mathrm{O}_{2}$ (US Department of Energy 1999).

Tahap oksidasi-Fenton meliputi pengaturan $\mathrm{pH}$ limbah cairan 3-6, penambahan katalis besi sebagai larutan $\mathrm{FeSO}_{4}$, dan penambahan perlahan-lahan $\mathrm{H}_{2} \mathrm{O}_{2}$. Jika $\mathrm{pH}$ limbah cairan terlalu tinggi, maka besi lebih cepat teroksidasi berubah menjadi $\mathrm{Fe}(\mathrm{OH})_{3}$ dan terjadi dekomposisi $\mathrm{H}_{2} \mathrm{O}_{2}$ (US Department of Energy 1999).

Berdasarkan parameter COD (kebutuhan oksigen kimia), nisbah $\mathrm{Fe}-\mathrm{H}_{2} \mathrm{O}_{2}$ adalah 1:5-1:10 (b/b) dengan konsentrasi besi < 25-50 mg/L dapat bereaksi selama 10-24 jam. Produk oksidasinya (asam organik) terpisah dari besi. Reagen Fenton ini cukup efektif sebagai pengolahan pendahuluan untuk limbah dengan nilai COD > $500 \mathrm{mg} / \mathrm{L}$ (Industrial Wastewater, 2007). Katalis besi dapat digunakan baik dalam bentuk garam fero $\left(\mathrm{Fe}^{2+}\right)$ maupun feri $\left(\mathrm{Fe}^{3+}\right)$. Hal ini dikarenakan sirkulasi perubahan kedua ion tersebut sangat cepat. Akan tetapi, jika konsentrasi reagen Fenton yang digunakan rendah $(<10-25 \mathrm{ppm}$ $\mathrm{H}_{2} \mathrm{O}_{2}$ ), maka lebih baik menggunakan garam fero (Industrial Wastewater, 2007).

Kecepatan reaksi reagen Fenton meningkat dengan peningkatan suhu (20-40 ${ }^{\circ} \mathrm{C}$ ). Namun, jika suhu reaksi $>40-50{ }^{\circ} \mathrm{C}$, peranan $\mathrm{H}_{2} \mathrm{O}_{2}$ sebagai pengoksidasi semakin berkurang karena dekomposisi $\mathrm{H}_{2} \mathrm{O}_{2}$ dipercepat. Selain suhu, kecepatan kerja reagen Fenton juga dipengaruhi oleh nilai $\mathrm{pH}$ (3-6) (Industrial Wastewater, 2007).

Mekanisme dasar penanganan Fenton proses terdiri dari oksidasi kimia dan koagulan kimia dari senyawa organik. Proses oksidasi Fenton secara normal terdiri atas empat langkah yaitu : penyesuaian $\mathrm{pH}$, reaksi oksidasi, netralisasi dan koagulasi.

Produksi radikal hidroksil dalam proses Fenton terjadi dengan menggunakan $\mathrm{Fe}_{2}$ dan $\mathrm{H}_{2} \mathrm{O}_{2}$ :

$$
\mathrm{Fe}^{2+}+\mathrm{H}_{2} \mathrm{O}_{2} \rightarrow \mathrm{Fe}^{3+}+\mathrm{HO}^{\circ}+\mathrm{HO}^{-}
$$

Radikal hidroksil merupakan oksidasi kuat yang dapat merusak substrat organik (RH) dengan cepat dan menyebabkan dekomposisi kimia dari suatu senyawa.

$$
\begin{aligned}
& \mathrm{RH}+\mathrm{HO}^{\circ} \rightarrow \mathrm{R}^{\cdot}+\mathrm{H}_{2} \mathrm{O} \\
& \mathrm{R}^{\bullet}+\mathrm{Fe}^{3+} \rightarrow \mathrm{R}^{+}+\mathrm{Fe}^{2+} \\
& \mathrm{R}^{+}+\mathrm{H}_{2} \mathrm{O} \rightarrow \mathrm{ROH}+\mathrm{H}^{+}
\end{aligned}
$$

Radikal hidroksil dapat bereaksi dengan $\mathrm{Fe}^{2+}$ atau hydrogen peroksida.

$$
\begin{aligned}
& \mathrm{HO}^{\circ}+\mathrm{Fe}^{2+} \rightarrow \mathrm{HO}^{-}+\mathrm{Fe}^{3+} \\
& \mathrm{HO}^{\circ}+\mathrm{H}_{2} \mathrm{O}_{2} \rightarrow \mathrm{H}_{2} \mathrm{O}+\mathrm{HO}_{2}
\end{aligned}
$$

$\mathrm{Fe}^{3+}$ yang terbentuk melalui reaksi (1) dan (5) dapat bereaksi dengan $\mathrm{H}_{2} \mathrm{O}_{2}$ dengan mekanisme yang melibatkan hidroksil dan radikal hidroperoksil :

$$
\begin{aligned}
& \mathrm{Fe}^{3+}+\mathrm{H}_{2} \mathrm{O}_{2} \leftrightarrow \mathrm{Fe}-\mathrm{OOH}^{2+}+\mathrm{H}^{+} \\
& \mathrm{Fe}^{-} \mathrm{OOH}^{2+} \rightarrow \mathrm{HO}_{2}+\mathrm{Fe}^{2+} \\
& \mathrm{Fe}^{2+}+\mathrm{HO}_{2} \cdot \rightarrow \mathrm{Fe}^{3+}+\mathrm{HO}_{2}^{-} \\
& \mathrm{Fe}^{3+}+\mathrm{HO}_{2}{ }^{-} \rightarrow \mathrm{Fe}^{2+}+\mathrm{H}^{+}+\mathrm{O}_{2}
\end{aligned}
$$

Dengan begitu substansi organik dapat dihilangkan melalui dua langkah diantaranya oksidasi dan koagulasi. Selain dari pada itu penyelesaian dari oksidasi tergantung pada perbandingan dari hidrogen peroksida sementara tingkat oksidasi adalah ditentukan oleh konsentrasi awal besi dan temperatur (Benatti et.al., 2006).

Dalam proses Fenton $\left(\mathrm{Fe} / \mathrm{H}_{2} \mathrm{O}_{2}\right)$ garam atau serbuk besi digunakan sebagai katalis. Dalam suasana asam serbuk besi bereaksi dengan hidrogen peroksida memproduksi ion besi. Dari segi pandangan lingkungan keuntungan dari implementasi serbuk besi $(\mathrm{Fe})$ sebagai ganti garam besi adalah penghindaran dari beban tak perlu sistem air menghadapi anion

\subsection{Adsorpsi}

Adsorpsi (penyerapan) adalah suatu peristiwa perubahan konsentrasi yang terjadi pada bidang batas antara dua fase, karena zat dari fase yang satu melekat pada fase yang lain (terjadi pada permukaan). Sedangkan fase penyerap (adsorbing fase) yang berfungsi mengasorpsi disebut adsorben dan zat yang terkonsentrasi atau teradsorpsi pada permukaan fase lain disebut adsorbat. Proses adsorpsi dapat digambarkan sebagai proses dimana molekul meninggalkan larutan dan 
menempel pada permukaan zat adsorben akibat kimia dan fisika (Reynold,1982).

Kekuatan interaksi adsorbat dengan adsorben dipengaruhi oleh sifat dari adsorbat maupun adsorbennya. Gejala yang umum digunakan untuk meramalkan komponen mana yang diadsorpsi lebih kuat adalah kepolaran adsorben dengan adsorbatnya. Apabila adsorbennya bersifat polar maka komponen yang bersifat polar akan terikat kuat dibandingkan dengan komponen yang kurang polar. Kekuatan interaksi juga dipengaruhi oleh sifat keras lemahnya dari adsorbat maupun adsorben. Sifat keras untuk kation dihubungkan dengan istilah polarizing power cation yaitu kemampuan suatu kation untuk mempolarisasi anion dalam suatu ikatan. Kation yang mempunyai polarizing power cation yang besar dimiliki oleh ion-ion logam dengan ukuran jari-jari kecil dan muatan yang besar. Sebaliknya sifat polarizing power cation yang rendah dimiliki oleh ion-ion logam dengan ukuran namun muatannya kecil sehingga diklasifikasikan ion lemah. Sedangkan pengertian keras untuk anion dihubungkan dengan istilah polarisabilitas anion yaitu kemampuan suatu anion untuk mengalami polarisasi akibat medan magnit dari kation. Anion yang bersifat keras adalah anion yang berukuran kecil bermuatan besar dan elektronegativitas yang rendah. Ion logam keras berikatan kuat dengan anion keras dan ion logam lemah berikatan kuat dengan anion lemah (Atkins et.al. di dalam Wulandari, 2010).

Porositas adsorben juga mempengaruhi daya adsorpsi dari suatu adsorben. Adsorben dengan porositas yang besar mempunyai kemampuan menyerap yang lebih tinggi dibandingkan dengan adsorben yang memiliki porositas kecil. Untuk meningkatkan porositas dapat dilakukan dengan mengaktifasi secara fisika seperti mengalirkan uap air panas kedalam pori-pori adsorben. Daya adsorpsi setelah diaktifasi akan meningkat dua kali lipat atau lebih dibandingkan daya adsorpsi sebelum diaktifasi (Setiawan et al. didalam Wulandari, 2010).

\subsection{Karbon Aktif}

Penggunaan karbon aktif sebagai suatu adsorben sudah dikenal sejak lama, selain dapat menghilangkan warna, rasa dan bau pada air yang ditimbulkan oleh mikroorganisme, karbon aktif juga dapat menghilangkan kandungan phenol dalam air. Karakteristik karbon aktif pada dasar meliputi sifat adsorbansinya dan sifat fisiknya yang meliputi total surface area, partcle density, effective size, coeficien uniformity, dll. Sedangkan sifat kimia dari permukaan (surface dan activated site) sangat menentukan terjadinya proses adsorbsi, yaitu cenderung untuk lebih mudah mengikat partikel yang mempunyai sifat yang sejenis, misalnya unsur yang kurang bersifat polar ( non polar ) akan lebih mudah terserap pada karbon non polar bila dibandingkan dengan yang bersifat polar. Jadi kecepatan adsorbsi untuk karbon aktif powder akan lebih cepat bila dibandingkan dengan karbon aktif tipe granular , total kapasitas adsorbsi dari karbon aktif tergantung pada total luas permukaan ,ukuran diameter tidak begitu mempengaruhi terhadap total luas permukaan, karena sebagian besar luas permukaan terletak pada pori - porinya

Karbon aktif adalah karbon atau material non polar berbentuk padatan berpori yang telah dilakukan proses karbonisasi dan aktivasi. Proses karbonisasi berfungsi untuk menghilangkan pengotor-pengotor serta zat volatil yang terdapat pada karbon sehingga kemurnian karbon menjadi meningkat, proses karbonisasi dilakukan dengan pemanasan sampai suhu sekitar $1.000{ }^{\circ} \mathrm{C}$.

Sedangkan proses aktivasi dilakukan untuk menciptakan pori-pori baru. Pori-pori yang terbentuk dapat meningkatkan luas permukaan dari karbon aktif. Melalui pori-pori tersebut, hidrogen akan diserap. Karbon aktif merupakan media yang efektif sebagai media padat penyimpanan hidrogen dibandingkan dengan activated carbon fiber, karbon aktif mempunyai kemampuan adsorpsi hidrogen yang lebih tinggi Jika dibandingkan dengan carbon nano tube (CNT), walaupun CNT mempunyai kapasitas adsorpsi yang lebih besar akan tetapi biaya pembuatan CNT lebih 
besar dan lebih sulit dibandingkan karbon aktif.

\section{METODOLOGI PENELITIAN}

\subsection{Jenis Penelitian}

Jenis penelitian yang dilakukan pada adalah penelitian kuantitatif dengan proses penelitiannya langsung melakukan observasi ke lapangan.

\subsection{Waktu dan Tempat Penelitian}

Kegiatan yang dilakukan untuk pengambilan data ini dilaksanakaan pada tanggal bulan April 2013 di Laboratorium Kimia Politeknik Negeri Sriwjaya.

\subsection{Alat dan Bahan}

Peralatan yang digunakan adalah peralatan gelas ukur, kolom adsorpsi, erlenmeyer, labu ukur, pipet ukur, pengaduk, neraca analitik, pompa vakum, Fenton reaktor dan bak penampungan.

Bahan-bahan yang digunakan dalam penelitian ini adalah limbah cair rumah sakit dari Post Treatment, koagulan tawas, karbon aktif, Fe dan Hidrogen peroksida

\subsection{Prosedur Kerja}

\section{Sampel}

\section{- Melakukan analisis limbah (sampel)}

Limbah cair yang dianalisis yaitu limbah cair rumah sakit yang keluar dari Instalasi Pengolahan Air Limbah (IPAL) rumah sakit atau post treatment pada tanggal 21 April 2013, sebanyak 10 liter. Sampel tersebut di ukur berdasarkan Peraturan Gubernur No. 8 tahun 2012 tentang baku mutu Limbah cair bagi kegiatan rumah sakit yang meliputi pH, COD, BOD, Phosfat, amoniak bebas dan mikroorganisme (bakteri). Limbah cair yang akan dianalisis variabelnya COD dan BOD karena belum sesuai baku mutu lingkungan. Tujuan analisa tahap pertama adalah mengetahui karakteristik limbah cair rumah sakit apakah memenuhi baku mutu air limbah rumah sakit, sehingga dapat diperkirakan metode yang bisa dilakukan untuk mengurangi kadar limbah yang masih ada.

- Penentuan Dosis Optimum Koagulan tawas Air baku tersebut diteliti dengan menggunakan Jartest, yang terdiri atas pengadukan cepat (rapid mixing) dan pengadukan lambat (slow mixing). Setelah pengadukan dengan putaran $60 \mathrm{rpm}$ air baku tersebut didiamkan mengendap sampai 15 menit. Setelah didiamkan mengendap air baku tersebut dilakukan uji laboratorium dengan mengukur parameterparameter yang nantinya akan menentukan dosis optimum koagulan dari limbah cair post treatment rumah sakit. Parameterparameter tersebut adalah $\mathrm{pH}, \mathrm{COD}, \mathrm{BOD}$, amoniak bebas dan mikroorganisme (bakteri). Pada penentuan dosis optimum koagulan limbah cair post treatment rumah sakit dilakukan Jartest dengan pemberian variasi dosis koagulan yang berbeda. Variasi dosis yang diberikan dimulai dari 2 $\mathrm{mg} / \mathrm{l}$ sampai dengan $36 \mathrm{mg} / \mathrm{l}$, dengan interval yang berbeda-beda.

- Proses Oksidasi Lanjutan (penambahan Fenton) dan Koagulasi

Tangki fenton yang berpengaduk dengan konsentrasi fenton $\mathrm{FeSO}_{4} 7 \mathrm{H}_{2} \mathrm{O} 4 \mathrm{mM}$ dan konsentrasi $\mathrm{H}_{2} \mathrm{O}_{2} 320 \mathrm{mM}$, perbandingan molar 1 : 80 dengan volume masing masing $100 \mathrm{ml}$. Tangki koagulasi berukuran panjang rusuk $35 \mathrm{~cm}$, dengan dosis tawas tertentu. Setelah dilewatkan ke Tangki koagulasi dialirkan ke reaktor oksidasi melalui outlet. Setelah waktu oksidasi ditambahkan natrium tiosulfat untuk menghentikan reaksi pada limbah keluar menuju adsorben karbon aktif setinggi $30 \mathrm{~cm}$ dengan variasi laju alir, yaitu $137 \mathrm{ml} / \mathrm{menit}, 110 \mathrm{ml} / \mathrm{menit}$ dan 82 $\mathrm{ml} / \mathrm{menit}$. Setelah dilewatkan diadsorban sampel diambil untuk kemudian diukur $\mathrm{pH}$, COD, BOD, amoniak bebas dan mikroorganisme (bakteri).

\section{HASIL DAN PEMBAHASAN}

\subsection{Hasil Penelitian}

\subsubsection{Hasil analisa Limbah Cair Rumah Sakit Sebelum Proses Pengolahan}

Berdasarkan hasil analisa sampel limbah cair rumah sakit sebelum mengalami pengolahan di inlet diperoleh data yang disajikan pada tabel 4.1: 
Penentuan dosis optimum koagulan dilakukan dengan menggunakan jar test dengan pemberian dosis koagulan yang bervariasi dan dilakukan uji laboratorium terhadap limbah cair yang telah di jar test dengan beberapa parameter yang harus diukur diantaranya, $\mathrm{pH}$, COD, BOD dan TSS. Tabel 2 berikut ini adalah hasil analisa jar test.

Tabel 4.2. Hasil Analisa Jar test

\begin{tabular}{|c|c|c|c|c|c|c|c|c|}
\hline \multirow[b]{2}{*}{ 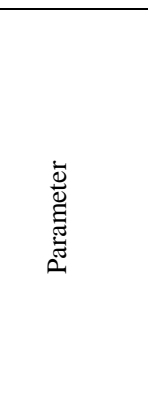 } & \multirow[b]{2}{*}{ 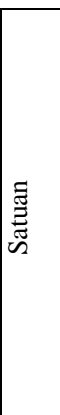 } & \multirow[b]{2}{*}{ 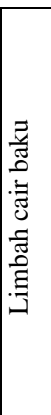 } & \multicolumn{5}{|c|}{ Dosis Tawas (ppm) } & \multirow[b]{2}{*}{ 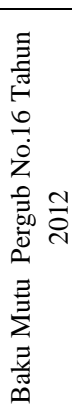 } \\
\hline & & & 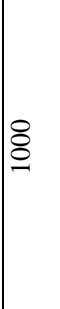 & $\stackrel{\wp}{\beth}$ & 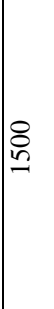 & 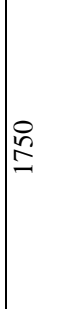 & ஓి & \\
\hline Temperatur & ${ }^{0} \mathrm{C}$ & $\mid \begin{array}{l}\sim \\
\infty \\
\stackrel{\sim}{c}\end{array}$ & $\infty$ & 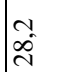 & $\begin{array}{l}n \\
\infty \\
\infty \\
\sim\end{array}$ & $\stackrel{\sim}{\sim}$ & $\stackrel{\infty}{\sim}$ & ిల \\
\hline $\mathrm{pH}$ & - & $\begin{array}{l}2 \\
\infty\end{array}$ & $\begin{array}{l}\partial \\
\infty\end{array}$ & $\frac{\sigma}{\infty}$ & in & $\infty$ & ñ. & $\begin{array}{l}a \\
1 \\
0\end{array}$ \\
\hline TSS & $\begin{array}{c}\mathrm{mg} \\
/ \mathrm{L}\end{array}$ & $\overline{\vec{N}}$ & $\begin{array}{l}\stackrel{\sim}{\Omega} \\
\stackrel{n}{2}\end{array}$ & 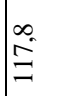 & $\frac{i}{a}$ & वें & $\begin{array}{l}\tilde{b} \\
\stackrel{\Omega}{\Xi}\end{array}$ & ిొ \\
\hline COD & $\begin{array}{c}\mathrm{mg} \\
/ \mathrm{L}\end{array}$ & $\begin{array}{l}\vec{\sim} \\
\stackrel{\infty}{=}\end{array}$ & 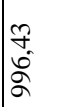 & $\begin{array}{l}\hat{b} \\
\stackrel{0}{\sigma}\end{array}$ & के & $\overrightarrow{\hat{i}}$ & 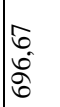 & $\infty$ \\
\hline $\mathrm{NH}_{3}$ bebas & $\begin{array}{c}\mathrm{mg} \\
/ \mathrm{L}\end{array}$ & ma & m. & 告 & 年 & 㹲 & $\stackrel{n}{m}$ & $\overline{0}$ \\
\hline BOD & $\begin{array}{c}\mathrm{mg} \\
/ \mathrm{L}\end{array}$ & $\begin{array}{c}m \\
\tilde{n} \\
\tilde{\sigma}\end{array}$ & $\begin{array}{l}\stackrel{+}{~} \\
\text { \& } \\
\stackrel{+}{+}\end{array}$ & $\begin{array}{l}\stackrel{\infty}{\sim} \\
\stackrel{\sim}{\sim}\end{array}$ & $\begin{array}{l}\overrightarrow{\text { ते }} \\
\text { तn }\end{array}$ & $\begin{array}{l}\text { बे } \\
\text { సे }\end{array}$ & $\begin{array}{l}\stackrel{n}{m} \\
\stackrel{m}{m}\end{array}$ & ిొ \\
\hline $\mathrm{PO}_{4}$ & $\begin{array}{c}\mathrm{mg} \\
/ \mathrm{L}\end{array}$ & $\stackrel{n}{f}$ & $\stackrel{\infty}{i}$ & $\underset{i}{\stackrel{0}{0}}$ & $\stackrel{\infty}{\sim}$ & $\hat{\mathrm{m}}_{2}$ & $\stackrel{n}{q}$ & N \\
\hline
\end{tabular}

Berdasarkan hasil analisa jar test (tabel 4.2) untuk parameter BOD, COD, TSS temperatur, $\mathrm{pH}$ dan $\mathrm{NH}_{3}$ bebas limbah cair rumah sakit mengalami penurunan pada setiap masing - masing dosis tawas. Pada dosis tawas $1.750 \mathrm{ppm}$, yaitu COD 1.183,4 mg/L dapat diturunkan sampai $529,1 \mathrm{mg} / \mathrm{L}$ dengan efisiensi penurunan (\%) sebesar $55,3 \%$, TSS $211 \mathrm{mg} / \mathrm{L}$ dapat diturunkan sampai $64,9 \mathrm{mg} / \mathrm{L}$ dengan persentase penurunan 69,2 \%, BOD $675,33 \mathrm{mg} / \mathrm{L}$ dapat diturunkan sampai 276,99 $\mathrm{mg} / \mathrm{L}$ dengan persentase penurunan $58,9 \%$ dan $\mathrm{pH}$ nilai nya dapat turun dari 8,99 dapat diturunkan sampai 6,8 dengan persentase penurunan $24,4 \%$ hal ini menunjukkan tawas dapat menurunkan $\mathrm{pH}$. Ion $\mathrm{Al}^{3+}$ dari tawas $\left(\mathrm{Al}_{2}\left(\mathrm{SO}_{4}\right)\right)$ yang terhidrolisis dalam air akan mengikat senyawa $\mathrm{OH}^{-}$dari air dan membentuk endapan $\mathrm{Al}\left(\mathrm{OH}_{3}\right)$ sehingga air menjadi kelebihan $\mathrm{H}^{+}$dan kemudian berikatan dengan senyawa sulfat membentuk asam sulfat. Pembentukan asam sulfat tersebut menyebabkan turunnya $\mathrm{pH}$ air.

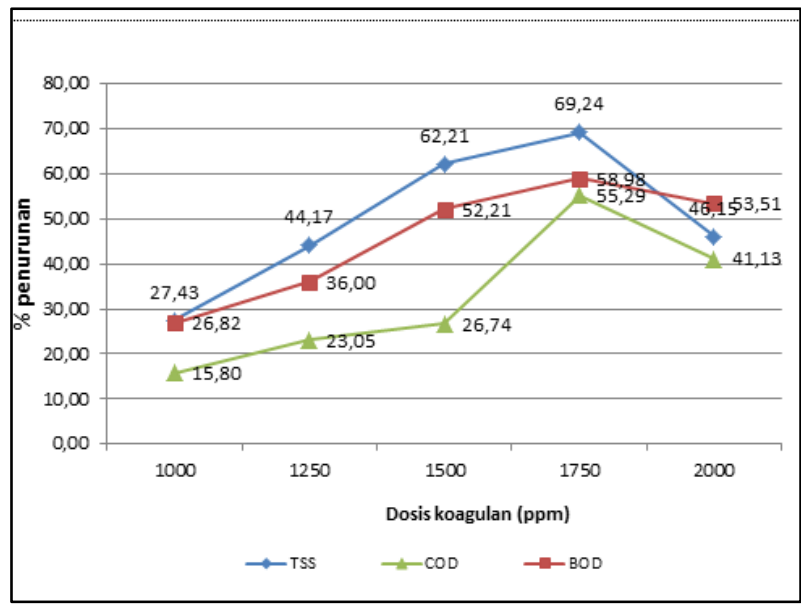

\section{Gambar 4.1. Grafik Persen Penurunan nilai BOD, COD dan TSS pada Limbah Cair Rumah Sakit dengan Metode Jar Test}

Mekanisme pengendapan dengan penambahan koagulan tawas (Alumunium Sulfat) adalah tawas dalam air akan terurai menjadi $\mathrm{Al}^{3+}$ dan mengalami hidrolisis membentuk $\mathrm{Al}(\mathrm{OH})_{3} \cdot \mathrm{Al}^{3+}$ inilah yang dapat menyebabkan destabilisasi partikel koloid, mengurangi gaya tolak menolak antar partikel koloid, sehingga partikel koloid dapat bergabung membentuk flok. Hasil hidrolisis tawas berupa $\mathrm{Al}(\mathrm{OH})_{3}$ memiliki kelarutan yang rendah dan permukaan cukup luas yang dapat menyerap partikel di sekitarnya dan mengendapkannya. Kelarutan $\mathrm{Al}(\mathrm{OH})_{3}$ dapat 
berubah-ubah bergantung pada $\mathrm{pH}$ koagulasi. Kelarutan $\mathrm{Al}(\mathrm{OH})_{3}$ dapat meningkat pada $\mathrm{pH}$ asam maupun basa, semakin asam maupun basa maka semakin tinggi kelarutan $\mathrm{Al}(\mathrm{OH})_{3}$. Kemampuan serapan tersebut dapat menurunkan kadar COD, BOD, TSS, dan logam yang terkandung dalam limbah cair.

Pada grafik di atas, pada volume tawas 1.750 ppm dianggap optimum karena pada volume tawas $2.000 \mathrm{ppm}$ terjadi kenaikan nilai parameter pencemar dapat dilihat pada grafik 1 berarti bahwa kadar tawas sudah jenuh dan menimbulkan pencemaran. Kadar COD pada tawas $2.000 \mathrm{ppm}$ meningkat jumlahnya menjadi 696,67 mg/L dalam limbah cair rumah sakit. Hal ini disebabkan oleh larutnya kembali ion - ion $\mathrm{Al}^{3+}$ dan juga terbentuknya garam - garam sulfat terlarut yang dihasilkan oleh hidrolisis tawas, tapi pada kandungan $\mathrm{NH}_{3}$ bebas kadar pencemarnya tidak berubah karena kemampuan alumunium sulfat atau tawas untuk mereduksi $\mathrm{NH}_{3}$ hanya sekitar 0,3 $\%$ efektifitas tertinggi pada 2 gr/L, setelah itu efektifitas alumunium sulfat terus mengalami penurunan, karakteristik $\mathrm{NH}_{3}$ di dalam air berbentuk Amonium $\mathrm{NH}_{4} \mathrm{OH}$. Bila senyawa ini kelebihan satu atom hidrogen $(\mathrm{H})$ maka senyawa ini berubah menjadi senyawa ionik yang bermuatan positif, bila amonium bereaksi dengan alum sulfat maka kedua senyawa akan mengalami kesulitan untuk bereaksi sehingga alum sulfat atau tawas kurang cocok untuk menurunkan kadar $\mathrm{NH}_{3}$

\subsubsection{Hasil Analisa Limbah Cair Rumah Sakit Setelah Proses Penambahan Reagen Fenton}

Hasil Analisa Fenton dengan konsentrasi $\mathrm{FeSO}_{4} 7 \mathrm{H}_{2} \mathrm{O} 4 \mathrm{mM}$ dan konsentrasi $\mathrm{H}_{2} \mathrm{O}_{2} 80 \mathrm{mM}$, perbandingan molar 1 : 20 dengan volume masing - masing $150 \mathrm{~m}$. Berdasarkan tabel di atas terlihat parameter yang di analisa seperti TSS, BOD, COD dan $\mathrm{NH}_{3}$ bebas mengalami penurunan nilai setelah ditambahkan dengan $\mathrm{FeSO}_{4} 7 \mathrm{H}_{2} \mathrm{O} 4 \mathrm{mM}$ dan konsentrasi $\mathrm{H}_{2} \mathrm{O}_{2} 80 \mathrm{mM}$, perbandingan molar 1 : 20 dengan volume masing - masing 150 ml. Berdasarkan Gambar 2 dapat diketahui bahwa penurunan COD maksimum sebesar $259,26 \mathrm{mg} / \mathrm{L}$ dosis optimum penambahan
$\mathrm{FeSO}_{4}$ sebesar 1:20 dengan $\mathrm{H}_{2} \mathrm{O}_{2}$. Hal ini menunjukkan komposisi antara katalis besi dan hidrogen peroksida seimbang sehingga pembentukan radikal hidroksil maksimum maka terjadi penurunan COD yang tertnggi. Perbandingan katalis besi dengan hidrogen peroksida yang lebih rendah menyebabkan kurang maksimalnya pembentukan radikal hidroksil karena sebagian hidrogen peroksida tidak stabil dan mengurai menjadi oksigen dan air maka kemampuan oksidasinya berkurang. Mekanisme kerja suatu radikal bebas terdiri dari tahap inisiasi (reaksi saat ikatan terlemah pada reaktan atau pada salah satu dari reaktanreaktan putus untuk menghasilkan radikal bebas), tahap propagasi (radikal bebas menyerang reaktan menghasilkan molekul produk dan spesies reaktif yang lain. Radikal bebas yang baru ini bereaksi lebih lanjut dan membentuk lagi radikal bebas yang semula, yang sekali lagi menyerang molekul reaktan.

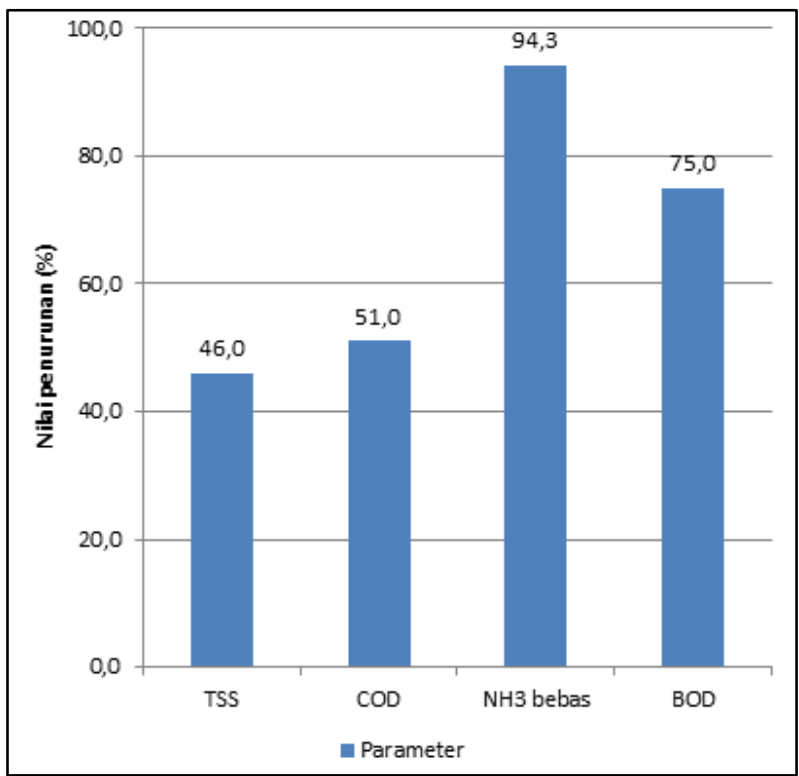

\section{Gambar 4.1. Diagram Penurunan nilai BOD, COD dan TSS}

Dengan jalan ini produk dan pembawa rantai terbentuk secara kontinyu), dan tahap terminasi (reaksi yang mengubah radikal bebas menjadi radikal bebas yang stabil dan tidak reaktif sehingga reaksi berakhir). Hal ini menunjukkan tahap radikal hidroksil untuk mengoksidasi zat organik membutuhkan waktu yang cukup lama karena kompleksnya 
zat organik dalam limbah dan mekanisme reaksi yang bertahap.

Hal ini dilihat dari besarnya persentase penurunan parameter yang dianalisis mencapai kadar optimum yang meliputi : Nilai COD $529,1 \mathrm{mg} / \mathrm{L}$ dapat diturunkan sampai 259,26 $\mathrm{mg} / \mathrm{L}$ dengan efisiensi penurunan $(\%)$ sebesar $51 \%$, TSS 64,9 mg/L dapat diturunkan sampai 35,05 $\mathrm{mg} / \mathrm{L}$ dengan persentase penurunan $46 \%$, BOD 276,99 $\mathrm{mg} / \mathrm{L}$ dapat diturunkan sampai 69,25 $\mathrm{mg} / \mathrm{L}$ dengan persentase penurunan $75 \%$ dan penurunan $\mathrm{NH}_{3}$ bebas dari $0,35 \mathrm{mg} / \mathrm{L}$ dapat diturunkan sampai $0,02 \mathrm{mg} / \mathrm{L}$ dengan persentase penurunan $94,3 \%$

\subsubsection{Data Hasil Analisa TSS, COD dan BOD Setelah Dialirkan ke Adsorben Karbon Aktif}

Hasil analisa kadar COD, BOD dan TSS dengan adsorben karbon aktif dengan berbagai variasi tinggi unggun tercantum pada tabel 3 dibawah, sedangkan tingkat efisiensi persentase penurunan kadar COD, BOD dan TSS tercantum pada grafik

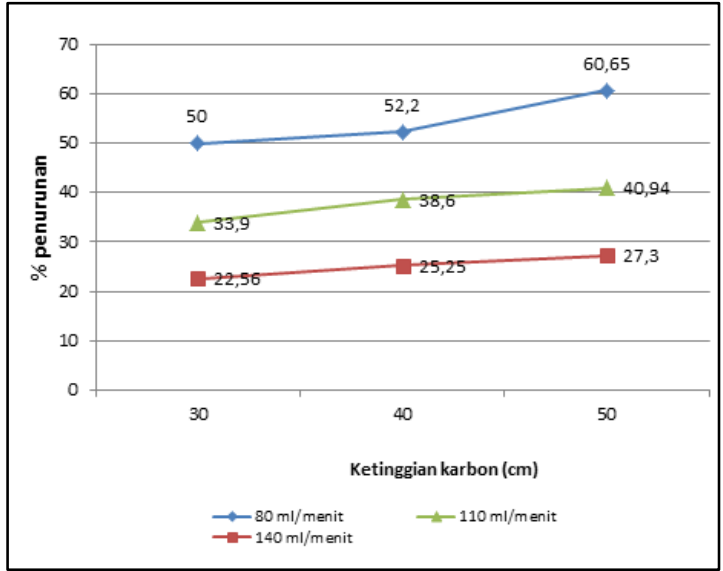

Gambar 4.1. Grafik Penurunan Kadar TSS

Dari penelitian ini dapat diketahui efisiensi karbon aktif terhadap penurunan kadar COD, BOD dan TSS untuk masing masing Tinggi unggun karbon aktif dan laju alir masuk yang telah ditetapkan. Semakin besar laju alir air limbah penurunan kadar COD, BOD dan TSS semakin kecil karena besarnya laju alir menyebabkan waktu kontak semakn cepat. Hal ini disebabkan karena dengan semakin tinggi unggun dengan kecepatan alir kecil persentase penurunansemakinbesar.

Pada Grafik 3 menunjukkan penurunan kadar TSS dengan variasi laju alir 80, 110 dan $140 \mathrm{ml} /$ menit pada Tinggi unggun 30, 40 dan $50 \mathrm{~cm}$, dilihat dari grafik bahwa makin besar laju alir limbah maka kadar pencemar yang terserap pada karbon aktif makin sedikit dari nilai TSS sebesar $35,05 \mathrm{mg} / \mathrm{L}$ menjadi 25,48 $\mathrm{mg} / \mathrm{L}$ persentase penurunannya hanya 27,30 $\%$ pada laju alir $140 \mathrm{ml} / \mathrm{menit}$ dan tinggi karbon $50 \mathrm{~cm}$ dikarenakan semakin besar laju alir limbah maka kontak limbah dengan media penyerap dalam hal ini permukaan karbon aktif sedikit atau terlalu cepat sehingga penyerapannya tidak efektif. Sedangkan pada laju alir $80 \mathrm{ml} / \mathrm{menit}$ dan tinggi karbon $50 \mathrm{~cm}$ nilai TSS 35,05 $\mathrm{mg} / \mathrm{L}$ turun menjadi 13,79 $\mathrm{mg} / \mathrm{L}$ dengan persentase penurunan $60,65 \%$ dikarenakan semakin lambat laju alir kontak antara limbah dengan permukaan karbon aktif semakin lambat sehingga penyerapan kadar pencemarnya semakin banyak dan efektif.

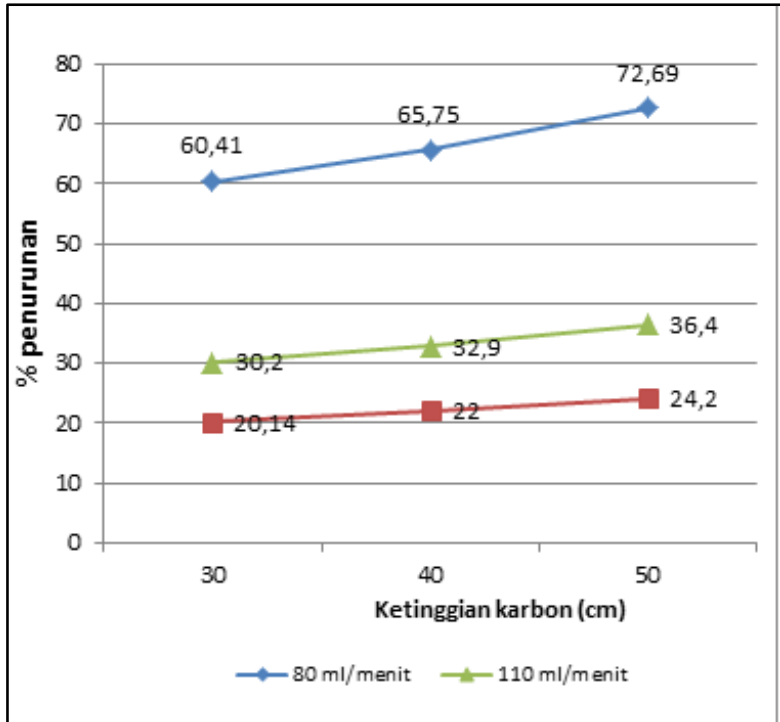

Gambar 4.1. Grafik Penurunan Kadar COD

Pada grafik 4 menunjukkan penurunan kadar COD dengan variasi laju alir 80, 110 dan $140 \mathrm{ml} / \mathrm{menit}$ pada Tinggi unggun 30, 40 dan $50 \mathrm{~cm}$. Dilihat dari grafik menunjukkan kadar COD mengalami penurunan nilai pada laju alir $80 \mathrm{ml} / \mathrm{menit}$ dan tinggi karbon $30 \mathrm{~cm}$ dari nilai 259,26 mg/L menjadi 102,26 mg/L dengan persentase penurunan $60,4 \%$. Dan 
pada laju alir $80 \mathrm{ml} / \mathrm{menit}$ dan tinggi karbon $50 \mathrm{~cm}$ nilai COD sebesar 259,26 mg/L menjadi $70,8 \mathrm{mg} / \mathrm{L}$ dengan persentase penurunan $72,7 \%$, pada kondisi tersebut menunjukkan bahwa semakin lambat laju alir dan semakin tinggi karbon aktif maka nilai COD akan semakin rendah hal ini disebabkan karena kontak limbah cair dengan karbon aktif menjadi semakin efektif.

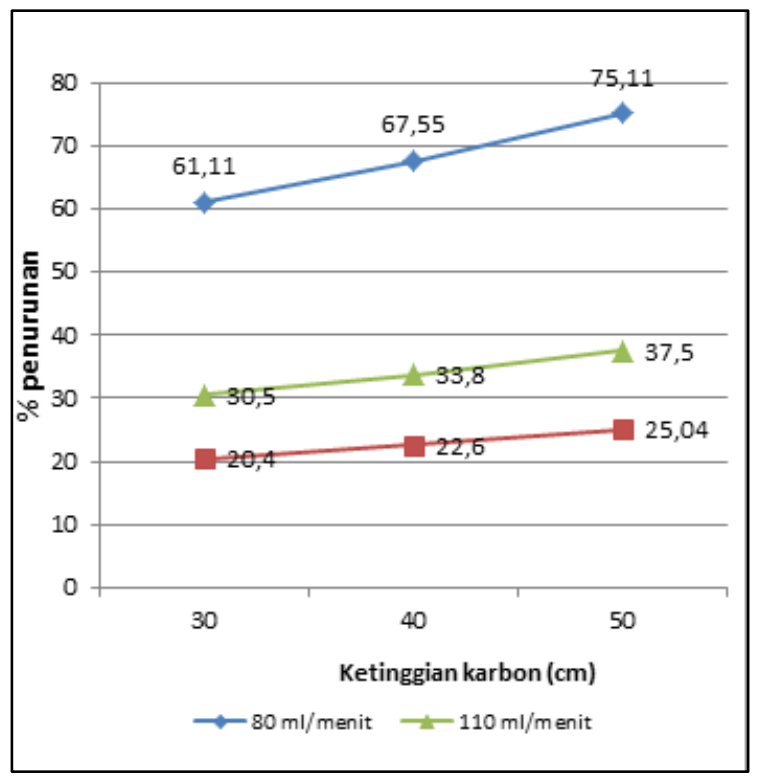

\section{Gambar 4.1. Grafik Penurunan Kadar} BOD

Pada grafik 5 menunjukkan Penurunan kadar BOD dengan variasi laju alir 80, 110 dan $140 \mathrm{ml} / \mathrm{menit}$ pada Tinggi unggun 30, 40 dan $50 \mathrm{~cm}$. Dilihat dari grafik bahwa semakin besar laju alir dan semakin rendah karbon aktif maka kadar BOD akhirnya semakin tinggi, dilihat dari laju alir $140 \mathrm{ml} / \mathrm{menit}$ dengan tinggi karbon $30 \mathrm{~cm}$ nilai BOD sebesar 69,25 $\mathrm{mg} / \mathrm{L}$ turun menjadi 55,12 $\mathrm{mg} / \mathrm{L}$ dengan persentase penurunan hanya $20,4 \%$ hal ini disebabkan karena kontak limbah cair dengan karbon aktif tidak sempurna karena laju alir yang terlalu cepat. Sedangkan penurunan kadar BOD pada tinggi karbon $50 \mathrm{~cm}$ dan laju alir $80 \mathrm{ml} / \mathrm{menit}$ turun sebesar $17,24 \mathrm{mg} / \mathrm{L}$ dengan efisiensi penurunan $75,11 \%$ hal ini disebabkan semakin lambat laju alir limbah cair maka akan semakin lama limbah cair tersebut kontak dengan media karbon aktif menyebabkan penyerapan yang dilakukan karbon aktif semakin baik, karena tinggi karbon aktif menyebabkan jumlah partikel solid menjadi semakin banyak dan berat sehingga luas permukaan kontak karbon aktif menjadi semakin besar pada saat limbah cair mengalir lambat melewati karbon aktif sehingga kontak antara solid (karbon aktif) dan liquid (limbah cair) semakin banyak sehingga jumlah zat pencemar yang terserap juga makin besar.

Dari analisa diatas pada variasi unggun $50 \mathrm{~cm}$ dan laju alir $80 \mathrm{ml} / \mathrm{menit}$ didapat nilai penurunan sebagai berikut : COD 259,26 mg/L dapat diturunkan menjadi $70,8 \mathrm{mg} / \mathrm{L}$ dengan persentase penurunan $72,69 \%$, TSS 35,05 $\mathrm{mg} / \mathrm{L}$ dapat diturunkan menjadi $13,79 \mathrm{mg} / \mathrm{L}$ dengan persentase penurunan $60,65 \%$ dan nilai BOD $69,25 \mathrm{mg} / \mathrm{L}$ turun menjadi 17,24 $\mathrm{mg} / \mathrm{L}$ dengan persentase $75,11 \%$. Efisiensi penurunan COD semakin besar disebabkan karena luas permukaan karbon aktif untuk mengadsorb bahan organik lebih besar.

\section{KESIMPULAN DAN SARAN \\ 5.1 Kesimpulan}

Dari penelitian yang telah dilakukan didapatkan kesimpulan bahwa

1. Kondisi optimum untuk penambahan koagulan tawas adalah sebanyak 1.750 ppm. Penambahan volume tawas di atas 1.750 ppm mengakibatkan kadar pencemar semakin tinggi karena kondisi tawas mulai jenuh dan mengakibatkan tawas menjadi pencemar.

2. Semakin rendah kolom adsorben dan semakin tinggi laju alir maka penyerapan kadar pencemar tidak efektif. Sebaliknya semakin tinggi kolom dan semakin lambat laju alir maka penyerapannya semakin efektif.

3. Kondisi optimum penyerapan karbon aktif adalah dengan laju alir $80 \mathrm{ml} / \mathrm{menit}$ dan tinggi karbon $50 \mathrm{~cm}$.

4. Limbah rumah sakit yang diolah dengan metode Koagulasi, reagen fenton dan adsorpsi sudah memenuhi baku mutu limbah cair, dengan diperoleh kadar TSS sebesar 6,78 mg/L, COD sebesar 70,8 mg/L 
dan BOD 17,4 mg/L.

\section{DAFTAR PUSTAKA}

Agustina, T.E. dan Aminzadeh B, Sarparastzadeh H, Saeedi M, Naeimpoor F. 2007. Pretreatment of municipal wastewater by enhanched chemical coagulation. International Journal of Enviromental Research. 1:104-113.

Ayuningtyas, Ratna Dewi. 2009. Proses Pengolahan Limbah Cair Di Rsud Dr. Moewardi Surakarta. Program D-III Hiperkes Dan Keselamatan Kerja Fakultas Kedokteran Universitas Sebelas Maret. Surakarta

Azamia, Mia. 2012. Pengolahan Limbah cair Laboratorium Kimia dalam Penurunan kadar Organik serta Logam Berat Fe, Mn, Cr dengan metode Koagulasi dan adsorpsi. Fakultas Matematika dan Ilmu Pengetahuan Alam. Universitas Indonesia. Depok

Baker FS, Miller CE, Repik AJ, Tollens ED. 1997. Activated carbon. Di dalam: Ruthven DM, editor. Encyclopedia of Separation Technology, Volume 1 (A kirk-Othmer Encyclopedia). New York: J Wiley.

Berti J, Rochenbach GC, Barreiros MA. 2009. Physico-chemical, microbiological and ecological evaluation of septic tank fenton reaction combination for the treatment of hospital wastewaters. Brazil

Danu Puguh Sanjaya, Iman Sukirman. 2010. Fakultas Kedokteran dan Ilmu Kesehatan Universitas Muhammadiyah.Yogyakarta

Deghani somayyeh, ahmad jonidi jafari. 2013. Solfonamide antibiotic reduction in aquatic enviroment by application of fenton oxidation process. Department of Environmental Health, Faculty of Medical Sciences, Tarbiat Modares University, Tehran, Iran

Depkes RI, 1995. Keputuan Menteri Lingkungan Hidup No. 58/MENLH/12/1995 tentang Baku Mutu Limbah Cair Bagi Rumah Sakit,Jakarta : Depkes RI.

Depkes RI, 2004. Keputuan Menteri Kesehatan No. 1204/MENKES/SK/2004 tentang Persyaratan Kesehatan Lingkungan Rumah Sakit, Jakarta : Depkes RI.

Eckenfelder WW, Jr. 2000. Industrial Water Pollution Control. Ed ke-3.The McGraw- Hill. Hlm: 470-474.

Inayah, 2009. Analisis Pengolahan dan karakterisik Limbah Cair di RSUD Dr. HM Rabain Muara Enim. Progaram Pascasarjana Universitas Sriwijaya Palembang.

Lelawati, 2008. Penurunan Kadar Polutan pada Pengolahan Limbah industry karet dengan Proses Aerasi dan koagulasi. Media infotama, Volume 3 No.6 Bulan 11 th. 2008

Ginting Perdana, 2007. Sistem Pengelolaan Lingkungan dan Limbah Industri, Bandung : CV. Yrama Widya.

Manes M. 1998. Activated carbon adsorption fundamental. Di dalam: Meyers RA, editor. Encyclopedia of Environmental Analysis and Remediation. Volume 1. New York: J Wiley.

Peraturan Gubernur Sumatera Selatan Tahun 2012

Reynolds, Tom D, 1982. Unit Operations and Processes in Environment Engineering. Brooks/Cole Engineering Division: California.

Risdianto Dian, 2007. Optimisasi Proses Koagulasi Flokulasi Untuk Pengolahan Air Limbah Industri Jamu ( Studi Kasus PT. Sido Muncul ). Program Pascasarjana Universitas Diponegoro Semarang.

Roy GM. 1995. Activated Carbon Applications in The Food and Pharmaceutical Industries. Pennsylvania: Technomic. 
San Sebastian Nora. 2003. Pre-Oxidation of an extremely polluted industrial wastewater of the fenton's reagent. Barcelona Spain.

Scrudato RJ, Chiarenzelli JR (2000) Electrochemical peroxidation of contaminated liquids and slurries. US Patent 6,045,707,4 Apr 2000

Strukul G. 1992. Catalytic Oxidations with Hidrogen Peroxide as Oxidant. The Netherlands: Kluwer.

Sudi Setyo Budi. 2006. Penurunan Fosfat Dengan Penambahan Kapur (Lime), Tawas Dan Filtrasi Zeolit Pada Limbah Cair (Studi Kasus Rs Bethesda Yogyakarta). Program Magister Ilmu Lingkungan Program Pascasarjana Universitas Diponegoro Semarang

US Department of Energy. 1999. Innovative technology: summary report. http://apps. em.doe.gov/OST/pubs/itsrs/itsr2161.pdf. [Diakses pada tanggal 24 Juli 2007]. 
P-ISSN: 2089-5925 E-ISSN: 2621-9328

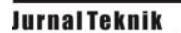

Jurnal Teknik Patra Akademika

PA

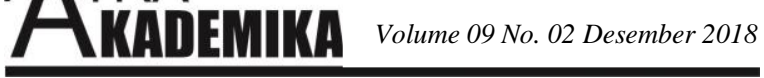

